\title{
The Speech Continuum Reconsidered: A Case Study of a Speaker of Indian English
}

\author{
James H. Yang \\ Department of Applied Foreign Languages, National Yunlin University of Science and Technology, Taiwan \\ Email: jamesyang1118@gmail.com
}

\begin{abstract}
This study highlights the dynamics of the speech continuum by analyzing the sound system of a speaker of Indian English (IndE). Utterances were collected via the reading of commonly spoken words and a semi-structured interview. The findings indicate that the speaker's sound features are much fewer than those described in earlier studies on IndE accents. Moreover, his pronunciation patterns display a mixture of the basilectal, meoslectal and acrolectal forms of Indian English, reflecting the characteristics of the non-linear speech continuum. This study concludes by discussing the speaker's sound patterns with relation to his sociolinguistic background.
\end{abstract}

Index Terms — speech continuum, Indian English, English accents, world Englishes

\section{INTRODUCTION}

Owing to misconceptions about language change and variation, nonnative varieties of English have long been regarded as being characterized by random or careless utterances (Nguyen, 1993; Rickford, 1999; Trudgill, 2004). A number of sociolinguistic studies have confirmed that the utterances of regional vernaculars such as African American English (AAE) are not disordered, but rather are governed by their own set of rules (Green, 2002). Similarly, creole varieties of English, such as Jamaican English, are not haphazard collections of random utterances, but rather consistent linguistic systems (Devonish, \& Seiler, 1991; Wassink, 1999). Likewise, the variety of English spoken as one of the official languages of India is not a degenerate or fossilized version of English, but, rather, a distinct form of English which exhibits systematic patterns and pragmatic functions (Agnihotri, 1991; Bansal 1978; Nihalani et at., 2004).

With regard to the various forms of English spoken worldwide, Trudgill (2004) hypothesized that they have been converging lexically due to the influence of American English, but are diverging phonologically. His diachronic study of the phonological affinity between British English, Australian English, and New Zealand English supports his hypothesis about the phonological divergence among different varieties of English Indian English (IndE) is not an exception. Earlier studies have demonstrated that IndE has evolved into a variety of English which is distinct from Received Pronunciation (RP), a process which began in the middle of the $18^{\text {th }}$ century, when India was gradually annexed by the British East India Company (e.g., Balasubramanian, 1972; Kelkar, 1957).

However, each ethnic or national variety of English is not a homogeneous entity, but consists of a wide range of variation, regional and social alike. IndE is an umbrella term for the diverse varieties of English currently used in India. Nonetheless, a number of mesolects have emerged, all of which are regarded as General IndE. In this respect, Gargesh (2008) has made an extensive description of the general phonology of IndE based on the speech of educated IndE speakers. Nonetheless, the speech continuum of sociolects and regiolects in IndE remains largely unexplored. Accordingly, this study analyzes the utterances of a speaker of IndE to investigate how his utterances reflect General IndE phonology (Gargesh, 2008; Mesthrie, 2008).

\section{LITERATURE REVIEW}

This study focuses on IndE because, of all the nonnative varieties of English, it has the largest number of speakers, and is used for both intra-national and international communication (Bolton \& Kachru, 2006; Kachru, 2004; Kachru \& Smith, 2008; Meierkord, 2006; Nihalani et al., 2004; Schneider, 2007). In terms of area, India is the seventh-largest country in the world, and with over 1.2 billion citizens, India's population is second only to China. Moreover, India is the world's largest democracy, and its economic output has expanded rapidly in recent decades. Kamdar (2007a, 2007b, 2007c) has described India's astonishing transformation from a developing country into a global powerhouse. Rothermund's (2008) India: The Rise of an Asian Giant provides an illuminating analysis of the new India and how it is likely to profoundly affect the globe culturally, politically and financially. Moreover, India is set to become one of the world's largest recipients of foreign investment and has a huge and highly skilled English-speaking workforce. A wide range of recent books have portrayed contemporary India as a dynamic country shifting from poverty to prosperity (Basu, 2004; Davies, 2008; Emmott, 2008; Fernandes, 2006; Lak, 2008; Meredith, 2007; Rajadhyaksha, 2007; Sengupta, 2005; Sheshabalaya, 2005; Smith, D.A., 2007; Tharoor, 2007). All of these phenomena demonstrate the current and future importance of IndE. 
Communicating in English with Indians can be enhanced by familiarity with IndE, and a host of scholars have begun to explore what can be regarded as its general phonology (Gargesh, 2008; Mesthrie, 2008; Nihalani et al., 2004). The following table displays Gargesh's (2008) phonological description of IndE in comparison with General American English (GAE) ${ }^{1}$ and RP. ${ }^{2}$

TABLE I.

THE VOWELS OF INDE ACCORDING TO WELL'S (1982) LEXICAL SET

\begin{tabular}{|c|c|c|c|}
\hline Word & IndE & RP & GAE \\
\hline Fleece & i: & i: & $\mathrm{i}$ \\
\hline Kit & I > i: & $\mathrm{I}$ & $\mathrm{I}$ \\
\hline Face & $\mathrm{e}:$ & eI & eI \\
\hline Dress & $\mathrm{e}>\varepsilon$ & $\varepsilon$ & $\varepsilon$ \\
\hline Trap & $æ>\varepsilon$ & $\mathrm{a}$ & $æ$ \\
\hline Bath & $\mathrm{a}:$ & $\mathrm{a}: \sim \mathrm{a}$ & $æ$ \\
\hline Strut & $\Lambda$ & $\Lambda$ & $\Lambda$ \\
\hline Palm & $\mathrm{a}:$ & $\mathrm{a}:$ & $\mathrm{a}$ \\
\hline Lot & $0>\mathrm{p}>\mathrm{a}$ & $\mathrm{p}$ & $\mathrm{a}$ \\
\hline Goose & $\mathrm{u}:$ & $\mathrm{u}:$ & $\mathrm{u}$ \\
\hline Foot & $U>\mathrm{u}:$ & $U$ & $U$ \\
\hline Goat & o: & $\partial U$ & $\mathrm{OU}$ \\
\hline Cloth & 0 & $\mathrm{p}$ & 0 \\
\hline Thought & 0: & o: & 0 \\
\hline Price & aI & $\Lambda \mathrm{I}$ & aI \\
\hline Choice & OI & गI & OI \\
\hline Mouth & aU & $\mathrm{au}$ & $\mathrm{au}$ \\
\hline Near & ID>Ir & IO & Ir \\
\hline Square & $\varepsilon:>\varepsilon r$ & $\varepsilon:$ & $\varepsilon r$ \\
\hline Nurse & $3:>3:$ & ว: & $3^{n}$ \\
\hline Start & $\mathrm{a}:>$ ar & $\mathrm{a}:$ & ar \\
\hline North & o: > or & o: & or \\
\hline Force & o: > or & ๑: & or \\
\hline Cure & Ijo: > Ijor & Uə 0: & jur \\
\hline Tuesday & Iju: & ju & $\mathrm{u}$ \\
\hline happY & $\mathrm{I}>\mathrm{i}$ & i & $\mathrm{i}$ \\
\hline lettER & $\partial>r$ & $\partial$ & $\mathrm{r}$ \\
\hline commA & $\mathrm{a}$ & $\partial$ & $\partial$ \\
\hline
\end{tabular}

First of all, both IndE and RP have non-rhotic accents. Although the r-less feature exists mostly in the educated variety of IndE, IndE is generally rhotic (Gargesh, 2008, p. 237). It is also noteworthy that the liquid /r/ is usually trilled in consonant clusters and in postvocalic positions. Gargesh added, "Although postvocalic realizations of $/ \mathrm{r} / \mathrm{might}$ be an instance of spelling pronunciation, it must be conceded that the English brought to India from the earliest times is likely to have its postvocalic r's intact"' (2008, p. 238).

Additionally, IndE pronunciation of vowels is closer to RP than GAE. The most striking difference is the GAE vowel /æ/ in words like bath, which is usually pronounced as /a:/ or /a/ in IndE and RP. Moreover, the GAE vowel /a/ is articulated at times as / $/$ or $/ \mathrm{p} / \mathrm{in} \mathrm{IndE}$ and RP.

The consonants of IndE also present phonological patterns, as illustrated below:

\footnotetext{
1 This study employs Heinle's Newbury House Dictionary of American English for sound comparison; it is available online: http://nhd.heinle.com/Home.aspx.

${ }^{2}$ Upton's (2008) description of RP is used as a point of reference in this study.
} 
TABLE II.

CONSONANTAL FEATURES OF INDE (ADAPTED FROM GARGESH, 2008, PP. 237-238)

\begin{tabular}{|c|c|c|}
\hline $\begin{array}{c}\text { Manner of } \\
\text { Articulation }\end{array}$ & IndE & Examples \\
\hline Stops & $\begin{array}{l}\text { Voiceless stops are not aspirated. } \\
\text { /t/ and /d/ tend to be retroflexed. }\end{array}$ & $\begin{array}{ll}- & \text { peace } / \text { pis/ } \\
\text { dog /dog/ }\end{array}$ \\
\hline Fricatives & 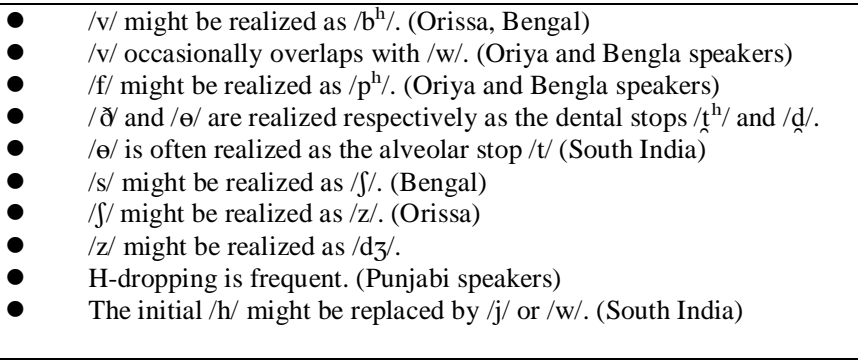 & 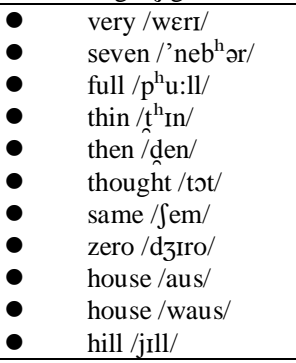 \\
\hline Affricates & $/ 3 /$ is usually realized as $/ \mathrm{d} 3 /, / \mathrm{z} /$, or $/ \mathrm{j} /$. & - $\quad$ pleasure /ple:dzər/ \\
\hline Nasals & $\begin{array}{l}\text { - } / \mathrm{y} / \text { is often realized as } / \mathrm{ng} / \text { when followed by the syllable-final velar } \\
\text { stop } / \mathrm{g} / \text { in a monosyllabic word. }\end{array}$ & $\begin{array}{ll} & \text { sing } / \operatorname{sing} / \\
\text { ring } / \mathrm{rIng} / \\
\end{array}$ \\
\hline Liquids & /r/ is generally trilled. & $\begin{array}{ll}- & \mathrm{car} / \mathrm{kar} / \\
& \mathrm{cry} / \mathrm{krai} /\end{array}$ \\
\hline Semi-vowels & $\begin{array}{l}\text { /w/ often overlaps with /v/. } \\
\text { /w/ and /j/ might be omitted when followed by a mid or close vowel. } \\
\text { /w/ and /j/ might be added word-initially. (South India) } \\
\text { /wh/ is preserved. } \\
\text { Syllabic rhythms, not stress-timed utterances }\end{array}$ & $\begin{array}{ll} & \text { window /'vindo:/ } \\
0 & \text { won't /o:nt/ } \\
0 & \text { yet /et/ } \\
\text { old /wo:ld/ } \\
\text { about /je'baut/ } \\
\text { where /wher/ }\end{array}$ \\
\hline Geminates & Double consonants frequently occur. & inner /'Innər/ \\
\hline Past-tense suffix & - Voiceless -ed is usually realized as /d/ & traced /tre:sd/ \\
\hline Others & $\begin{array}{l}\text { No syllabic consonant formation } \\
\text { Schwa deletion occurs sometimes in light positions. } \\
\text { Consonant clusters are sometimes simplified. } \\
\text { / } \quad \text { I/ or /i/ insertion in the word-initial position in a consonant cluster } \\
\text { (Uttar Pradesh, Bihar) } \\
\quad \text { Schwa insertion between a consonant cluster (Punjab, Haryana) } \\
\text { Schwa insertion in - nst \# (South India) }\end{array}$ & $\begin{array}{ll} & \text { metal /metəl/ } \\
0 & \text { allegory /ə'legri/ } \\
\text { - } & \text { fruits /frut/ } \\
\text { school /'isku:1/ } \\
\text { school /'səku:1/ } \\
\text { - } \\
\text { against /age:nəst/ }\end{array}$ \\
\hline
\end{tabular}

In contrast to the mesolectal IndE features presented above, some basilectal or broad sound features are displayed below (Bansal, 1969; Masica, \& Dave, 1972; Nihalani et al., 2004; Wells, 1982):

TABLE III.

SOUND FEATURES OF BASILECTAL INDE

\begin{tabular}{|c|c|}
\hline Sound Features & Examples \\
\hline 1. Substitution of $/ \mathrm{au} /$ for $/ \mathrm{J} /$ & now $\rightarrow$ gnaw \\
\hline 2. $\quad$ Substitution of /æ/ for /aI/ & man $\rightarrow$ mine \\
\hline 3. $\quad$ Substitution of $/ \varepsilon /$ for $/ \mathrm{e} /$ & men $\rightarrow$ main \\
\hline 4. $\quad$ /f/ for the word $o f$ & of /of/ \\
\hline 5. $\quad / \mathrm{w}^{\mathrm{h}} /$ or $/ \mathrm{v}^{\mathrm{h}} /$ for $w h$-words & which $/ \mathrm{w}^{\mathrm{h}} \mathrm{It} \int /$ or $/ v^{\mathrm{h}} \mathrm{It} \int /$ \\
\hline 6. $\quad / \mathrm{s} /$ for the plural suffix after a voiced consonant & Dogs /dogs/ \\
\hline 7. $\quad$ Substitution of /1/ for syllable-initial /r/ & very /'veli/ \\
\hline
\end{tabular}

Drawing on the sound patterns of IndE as presented above, this study investigates the speech continuum in IndE by examining how an IndE speaker's utterances reflect the general phonology of IndE. The subsequent section details the methodology used for data collection and sound analysis.

\section{Methodology}

\section{A. Research Questions}

The participant is referred to by the pseudonym Raj, who was 24 years old at the time of the study. He was born and raised in Agra, a city about 200 kilometers south of Delhi, located in Uttar Pradesh, India's most populous state. Raj just came to the US two months ago to study business management in pursuit of his master's degree. He speaks Hindi as his mother tongue, which is the most widely spoken language in north India. Hindi is also the official language of India, whereas English is the subsidiary official language. Hindi is spoken as a first language by $30 \%$ of the population, and as a second language by around $28 \%$. In India and abroad, about 500 million people speak Hindi, and the total number of people who can understand the language is estimated at 800 million. Hindi is thus the second most widely-spoken language in the world, after Mandarin Chinese. Additionally, there are thirteen dialects of Hindi in India, among which Khadiboli (or Sarhindi), spoken in Western Uttar Pradesh, was used by the government for the standardization of Hindi 
in the 1950s. ${ }^{3}$ Although Hindi is the main language in Uttar Pradesh, other local languages of the state include Awadhi, Bundeli, Braj Bhasha, Kannauji, Khari Boli, Bhojpuri, and Bagheli. These languages are promoted by the state government in cultural festivals, but are usually regarded as negligible in formal education.

In the interview, Raj said that he spoke English as a second language when interacting with his friends who did not speak Hindi. However, he emphasized that with three of his closest friends he spoke Hindi most of the time, because they all spoke Hindi as their native language. With Raj as the speaker, this study addressed the following questions:

(1) What is the sound system underlying Raj's utterances?

(2) How frequently do Raj's sound features occur?

(3) How are Raj's sound patterns similar to or different from General IndE phonology?

\section{B. Data Collection}

Speech samples were collected by having Raj read a list of common spoken words, and his sound features were compared with those of General IndE (Gargesh, 2008; Mesthrie, 2008).

The reading of a word list was used because, when reading such a list, the participant is very likely to use a more formal pronunciation, as would be done when interacting with strangers from other ethnic groups or nations. There is evidence that English speakers tend to speak as formally as they can in international communication in order to avoid misunderstanding or non-understanding. Jenkins (2000) found that nonnative English speakers often constrain consonant cluster simplification and avoid the use of weak-form pronunciation (such as the use of from /fr $\Lambda \mathrm{m} /$, rather than /frəm/), since doing so helps to enhance their intelligibility to unfamiliar interlocutors. Accordingly, this study examines the sound patterns that Raj is most likely to exhibit in a formal presentation or an initial interaction with other English speakers. After the reading task, an interview was conducted with Raj to further explore his use of English in daily life.

\section{Test Words for the Reading Task}

This study used 1,000 commonly spoken English words retrieved from 60 recent interviews on the Oprah Winfrey Show. ${ }^{4}$ The test words consisted of high-frequency concept words in their basic forms (e.g., write), and excluded graphic words (e.g., writes, wrote, written, and writing). This lexical decision was made because intelligibility is not affected by irregular finite forms and plural/tense suffixes, because the meaning is usually made clear by the context, as shown in such utterances as He go home yesterday, He like her, and He don't eat shrimp.

However, some concept words were deleted, including proper nouns, culturally specific words, and function words. Furthermore, some were changed into their graphic forms for the word-reading task because close inspection reveals that the graphic forms appear much more frequently in Winfrey's interviews. Some of these graphic words are presented below:

TABLE IV.

SOME OF THE CONCEPTS WORDS REPLACED WITH THEIR GRAPHIC COUNTERPARTS

\begin{tabular}{|l|l|}
\hline Concept word & Graphic word \\
\hline Morn & Morning \\
\hline Injure & Injured \\
\hline Probable & Probably \\
\hline Exact & Exactly \\
\hline Absolute & Absolutely \\
\hline Definite & Definitely \\
\hline Especial & Especially \\
\hline Immediate & Immediately \\
\hline Excite & Exciting \\
\hline Shoe & Shoes \\
\hline
\end{tabular}

The 1,000 test words are considered to be sufficient because an analysis of 10 of Winfrey's interviews indicates that out of a total of around 81,000 words spoken in the interviews, only around 3,800 are concept words.

This study did not employ an already existing corpus of spoken English because some are slightly out-of-date (e.g., the London-Lund Corpus, launched in 1959), some are built on academic English (e.g., the Michigan Corpus of Academic Spoken English), and some are limited to a single topic (e.g., the Switchboard Telephone Speech Corpus, and the Corpus of Business Communications established by the Brigham Young School of Management). By contrast, this study used a popular American talk show to construct a corpus of high-frequency words because the hostess and interviewees of various backgrounds discuss common topics concerning everyday life, making it a good source for commonly spoken English words.

Although the small-scale corpus established for this study primarily reflects spoken American English and might not be highly representative of other varieties of English, some studies have demonstrated that there is a close correspondence of high-frequency words (excluding proper nouns) among different varieties of English (Hofland \&

\footnotetext{
${ }^{3}$ The information about Hindi appears on Wikipedia: http://en.wikipedia.org/wiki/Main_Page.

${ }^{4}$ For a description of the Oprah Winfrey television show, visit www.oprah.com.
} 
Johansson, 1982; Ljung, 1990; Peyawary, 1999).

Raj's reading of the test words was recorded and transcribed by ear for sound analysis. A research assistant with knowledge of phonetics and phonology made the initial transcription, which was later checked by the researcher. The few discrepancies which were found were resolved after re-examination and discussion. Additionally, to explore the frequency of Raj's sound features, we adapted Meade's (2001) categorization of sound alterations, as shown below:

TABLE V.

\begin{tabular}{|c|c|} 
CLASSIFICATION OF PHONOLOGICAL FREQUENCY (ADAPTED FROM MEADE, 2001, P. 85) \\
\hline Occurrence Percentage & Usage Frequency \\
\hline $90 \%-100 \%$ & Complete usage \\
\hline $75 \%-89 \%$ & Full usage \\
\hline $50 \%-74 \%$ & Regular usage \\
\hline $25 \%-49 \%$ & Inconsistent usage \\
\hline $1 \%-24 \%$ & Sporadic usage \\
\hline 0 & Absent usage \\
\hline
\end{tabular}

\section{FINDINGS}

The most notable sound feature in Raj's reading is his r-less accent, a common characteristic of educated speakers of IndE (Sailajia, 2009). Like most speakers of British English, Raj did not pronounce the syllable-final r-sound as a retroflex, but rather as schwa, as in the word hair ['heə]. The vocalic /r/ is sometimes dropped with the previous vowel prolonged, as in car [ka:]. This non-rhotic accent, however, is not regarded as a sound feature of General IndE phonology (Gargesh, 2008, p. 237).

Raj's articulation also exhibits a phonological feature typical of British English: the insertion of the palatal glide /j/ in /ju/ after coronals. Upton (2008) commented, "Yod coalescence is actually a general feature of RP...heard regularly for example in attitude, residue, tissue, and usual" (p. 249). He added, though, "Yod deletion is similarly characteristic word-initially in RP in such words as super and suit" (p. 250). He concluded, "Coalesced forms are becoming increasingly apparent in all positions in RP, where they provide a less formal alternative to the more 'careful' forms" ( $\mathrm{p}$. 249). In this study, Raj pronounced the glide /j/ before the stressed vowel / $\mathrm{u} /$ in such words as during, new, and news, but not in student and suit. This sound pattern occurred as a regular usage because it appeared $67 \%$ of the time in Raj's reading.

By comparison, the glide insertion is frequently lost in GAE, as in Tuesday, coupon, and neurotic, but regularly appears in several other words, such as cure and music (Kretzschmar, 2008, p. 48). Likewise, Boberg (2008, p. 157) noticed that the loss of $/ \mathrm{j} /$ in North American English seems "to be diffusing rapidly over most of the continent, including Canada," as indicated in such words as news, student, and tube.

Another phonological feature of British English found in Raj's reading is the vowel shift from /æ/ to /a/. For example, Raj said [ask] for ask, ['ansə] for answer, and [pas] for pass. The occurrence of this vowel shift, however, is inconsistent, occurring only $34 \%$ of the time.

Another phonological feature is the realization of $/ \mathrm{ng} /$ for the velar nasal coda in a stressed syllable. For instance, he articulated [ring] for ring, [rong] for wrong, and [hæyg] for hang. This pattern appears 69\% of the time, making it a regular usage.

Raj also tended to pronounce the unstressed ending -ing as /In/, as found in his pronunciations of such words as ['sevin] for saving and ['EnItIn] for anything. This sound modification appears frequently enough to be classified as a regular usage.

Furthermore, Raj also frequently pronounced the syllable-initial consonant /r/ as /l/, as in serious ['silıəs], very ['veli], and reason ['lizn]. Although Gargesh (2008) remarked that the liquid /r/ is generally trilled, we perceived it as /1/. Our acoustic analysis of Raj's pronunciation of very and family indicates that the formants of the final syllables are close, and their spectrograms look nearly identical to each other, as shown below:
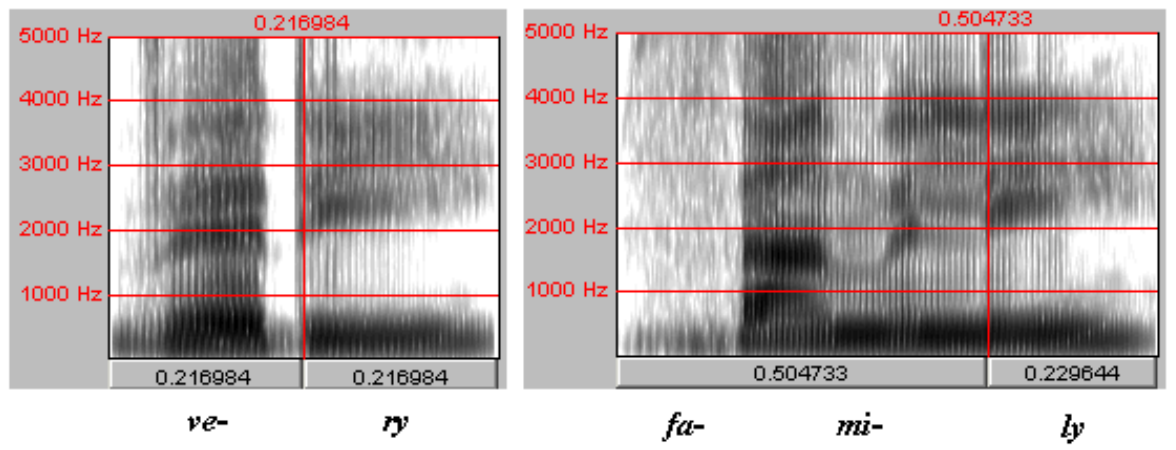

Figure 1. Spectrographic comparison between very (left) and family (right) in Raj's reading 
This consonant substitution, however, occurs only $36 \%$ of the time, and thus is classified as an inconsistent usage.

In addition, Raj often pronounced the interdental fricatives $/ \delta /$ and $/ \Theta /$ as the dental stops $/ \mathrm{d} /$ and $/ \mathrm{t} /$, respectively. For instance, he said [de] for they. Interestingly, word-final, interdental fricatives were also changed into a stop. For example, Raj articulated the word bath with the final /t/ aspirated. The acoustic analysis demonstrates that the final th is aspirated because its duration is noticeably more protracted than the final $t$ consonant in but, as displayed below:
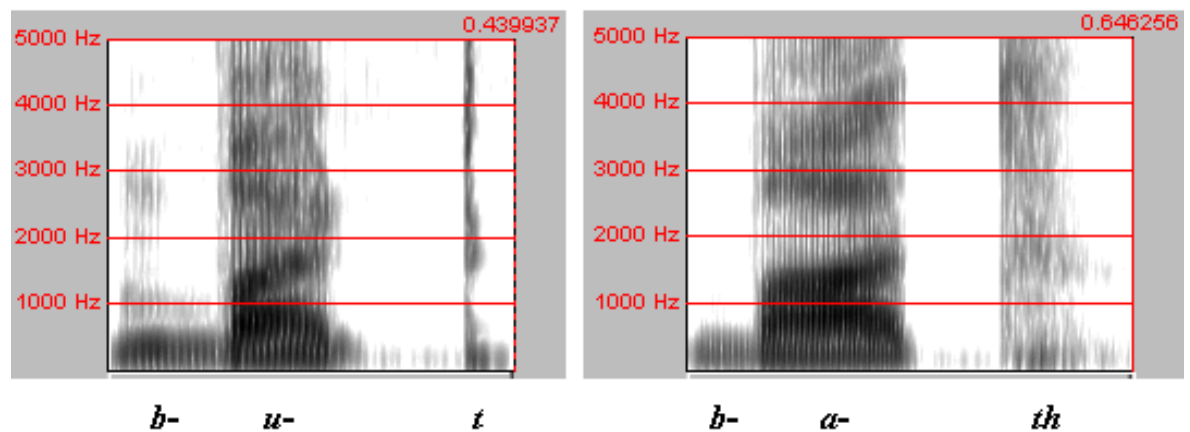

Figure 2. Spectrographic comparison between but (left) and bath (right) in Raj's reading

This sound alteration is in full usage in his reading.

The most notable sound feature in Raj's reading is that he mostly pronounced voiceless stops with unaspiration when they were in the syllable-initial position, frequently enough to be classified as a full usage. For instance, Raj pronounced two like do, and pick like big.

The most peculiar sound feature in Raj's reading is the substitution of /v/ for /w/, and vice versa. For instance, he enunciated [wors] for voice and [vIf] for wish. This bi-directional substitution, however, is an inconsistent usage because it appears less than $40 \%$ of the time. Nonetheless, $/ \mathrm{wh} /$ is fully preserved in Raj's reading. Below is a summary of the sound patterns found in Raj's reading:

TABLE VI.

THE SOUND FEATURES FOUND IN RAJ'S READING

\begin{tabular}{|c|c|c|}
\hline Phonological feature & Example & Occurrence rate \\
\hline 1. $\quad$ Syllable-final, r-less accent & water $\rightarrow$ ['wotə] & $100 \%$ (complete) \\
\hline 2. Glide insertion before stressed /u/ & new $\rightarrow[$ nju $]$ & $67 \%$ (regular) \\
\hline 3. $\quad$ preservation of /wh/ & where & $100 \%$ (complete) \\
\hline $\begin{array}{l}\text { 4. Realization of the unstressed rhyme /Iy/ } \\
\text { as /In/ }\end{array}$ & anything $\rightarrow$ ['EnIधIn] & $60 \%$ (regular) \\
\hline 5. $\quad$ Unaspiration of voiceless stops & $\begin{array}{l}\text { two } \rightarrow \text { do } \\
\text { pick } \rightarrow \text { big }\end{array}$ & $100 \%$ (complete) \\
\hline $\begin{array}{l}\text { 6. Realization of interdental fricatives as } \\
\text { dental stops }\end{array}$ & $\begin{array}{l}\text { thin } \rightarrow[\text { tin }] \\
\text { with } \rightarrow[\text { wit }]\end{array}$ & $\begin{array}{l}\text { Syllable-initial: } 75 \% \text { (full) } \\
\text { Syllable-final: } 100 \% \text { (complete) }\end{array}$ \\
\hline $\begin{array}{l}\text { 7. Preservation of } / g / \text { after } / \mathrm{y} / \text { in a stressed } \\
\text { syllable }\end{array}$ & ring $\rightarrow$ [ring] & $69 \%$ (regular) \\
\hline 8. $\quad$ Substitution of $/ / /$ for syllable-initial $/ \mathrm{r} /$ & very $\rightarrow$ ['velI] & $36 \%$ (inconsistent) \\
\hline 9. $\quad$ Shift between /v/ and /w/ & $\begin{array}{l}\text { voice } \rightarrow[\text { woIs }] \\
\text { wish } \rightarrow[\text { vif }]\end{array}$ & $\begin{array}{l}/ \mathrm{v} / \rightarrow / \mathrm{w} /: 37 \% \text { (inconsistent) } \\
/ \mathrm{w} / \rightarrow / \mathrm{v} /: 32 \% \text { (inconsistent) }\end{array}$ \\
\hline 10. Vowel shift from $/ æ /$ to $/ \mathrm{a} /$ & ask $\rightarrow[$ ask $]$ & $34 \%$ (inconsistent) \\
\hline
\end{tabular}

Actually, the first two features also exist in RP. The third feature, the preservation of /wh/, also appears in RP, but it has declined and is rapidly changing into /w/ (Upton, 2008). However, the most striking vowel shift of RP-from /æ/ to /a/, which makes both RP and General IndE differ from GAE — appears only inconsistently in Raj's reading. Moreover, the vowel shift that makes IndE distinct from both RP and GAE - the change from / $/$ / to /e/, as in the word dress - does not appear at all in Raj's reading.

As a whole, all of Raj's sound features are consonantal modifications, except for the infrequent vowel change from /æ/ to /a/. Accordingly, Raj's vowel system does not include any vowel merger, as shown below: 


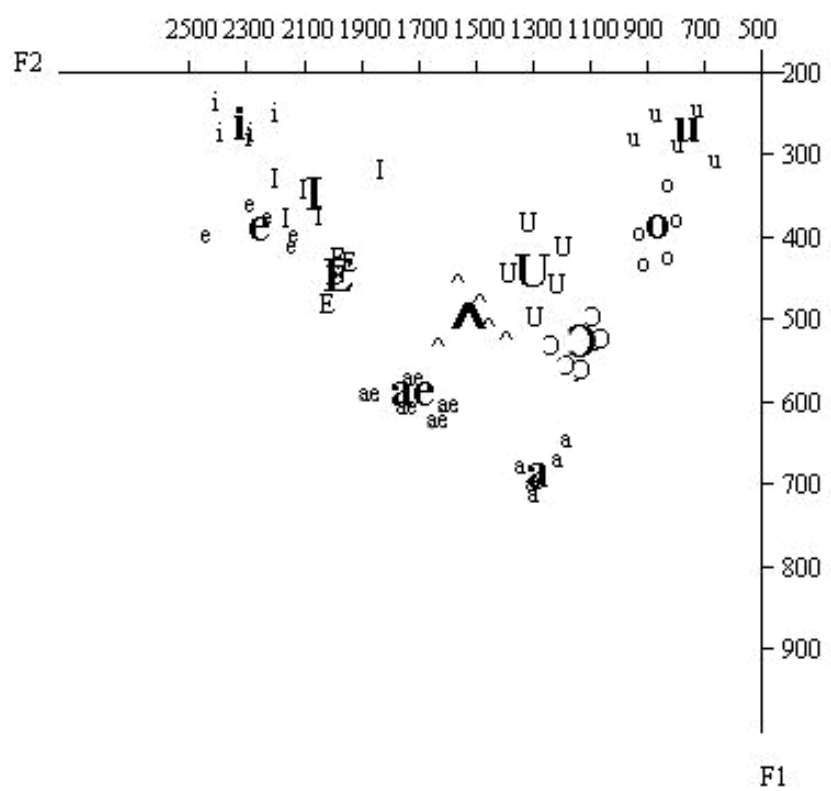

Figure 3. Raj's vowel chart

Taken together, most of Raj's vocalic patterns reflect General IndE phonology, but the lax vowel, as in dress, does not change into its tense counterpart. By comparison, the consonantal features exhibited by Raj are much fewer than those usually ascribed to speakers of IndE, as shown in Table 2 (Gargesh, 2008; Mesthrie, 2008). These findings demonstrate that Raj's pronunciation does not reflect all of the sound patterns typical of General IndE phonology, displaying the dynamic trajectory of the speech continuum in IndE. All in all, Raj's pronunciation indicates the existence of phonological variation in IndE, GAE and BE, in support of the Phonological Divergence Theory posited by Trudgill (2004).

\section{CONCLUSion}

This study has shown that Raj's English pronunciation is not random, but rather exhibits phonological patterns, despite varying rates of occurrence. A total of ten sound features are found in Raj's pronunciation; among which, seven occur regularly, whereas the others appear only sporadically. These frequent features include the non-rhotic accent, the unaspiration of syllable-initial stops, the glide insertion before stressed /u/, the preservation of /wh/, the realization of interdental fricatives as dental stops, the preservation of $/ \mathrm{g} / \mathrm{after} / \mathrm{g} /$ in a stressed syllable, and the realization of the unstressed rhyme $/ \mathrm{ry} /$ as $/ \mathrm{m} /$.

By and large, Raj exhibits a British English accent in his complete use of the r-less accent, and his regular use of glide insertion before stressed /u/. Nevertheless, the prominent vowel shift from /æ/ to /a/ in British English appears to be only an inconsistent feature in Raj's pronunciation, although it has been described in earlier studies as a regular feature of basilectal IndE (Nihalani et al., 2004).

It is noteworthy that Raj's non-rhotic accent is not regarded as characteristic of General IndE phonology, but, rather, is a feature used mostly by educated speakers of IndE (Gargesh, 2008). Nonetheless, four regular phonological patterns distinguish Raj's pronunciation from that of a speaker of British English: the unaspiration of voiceless stops, the stopping of interdental fricatives, the preservation of $/ \mathrm{g} /$ after $/ \mathrm{g} /$, and the realization of $/ \mathrm{m} / \mathrm{for}$ unstressed $/ \mathrm{in} /$. Among these consonantal features, the realization of the unstressed rhyme $/ \mathrm{in} / \mathrm{as} / \mathrm{m} /$ is actually not a distinctive feature in General IndE phonology, but it is commonly used by native English speakers in informal settings, and it is also common in many nonstandard varieties of English as well (Jenkins, 2006; Wassink, 1999; Wolfram \& Schilling-Estes, 1998).

Perhaps the most unique feature of Raj's pronunciation is his complete use of the realization of interdental fricatives as dental stops. Although this feature is also common in many nonstandard varieties of English, its appearance in syllable-final positions, as in such words as with [wit], bath [bat], and death [det], is a distinctive, even idiosyncratic, feature. However, this pattern might have been the result of orthographical enunciation in the reading task, and this feature might not be the way Raj normally spoke.

Moreover, the substitution of /1/ for syllable-initial /r/ - a broad feature of IndE - appears only inconsistently in Raj's pronunciation. Interestingly, Raj does not display a common feature that is usually associated with the pronunciation of speakers of IndE from Uttar Pradesh: /I/ or /i/ insertion in the word-initial position in a consonant cluster, as shown in school /'səku:1/.

To summarize, Raj's pronunciation not only exhibits a distinct sound system different from RP and GAE, but also displays some phonological variation from General IndE. In fact, his sound patterns seem to be a mixture of basilectal, meoslectal and acrolectal IndE, which is not surprising, given the dynamics of the speech continuum in IndE. 
Because this study only examined Raj's reading pronunciation, follow-up research might examine inter-speaker variation via a comparison, for example, between his reading and his spontaneous utterances in conversation with a close friend. Furthermore, for the same reason, future research might compare Raj's sound patterns with those of other Indians who share similar sociolinguistic backgrounds. In particular, it would be intriguing to investigate whether the distinctive features of Raj's pronunciation found in this study - the realization of voiceless syllable-final interdental fricatives as unvoiced dental stops - are merely idiosyncratic, or are also exhibited by other Indians his speech community.

\section{ACKNOWLEDGMENTS}

The author wishes to thank Taiwan's National Science Council because part of this research was conduced under its auspices (NSC 98-2410-H-224-015).

\section{REFERENCES}

[1] Agnihortri, R. K. (1991). Sound patterns of Indian English: A sociolinguistic perspective. In R. S. Gupta \& K. Kapoor (eds.), English in India: Issues and problems. Delhi: Academic Foundation, 175-188.

[2] Bansal, R. K. (1969). The intelligibility of Indian English: Measurements of the intelligibility of connected speech, and sentence and word material, presented to listeners of different nationalities. Hyderabad, India: Central Institute of English.

[3] Bansal, R. K. (1978). The phonology of Indian English. In R. Mohan (eds.), Indian writings in English. Madras: Orient Longman, 101-113.

[4] Basu, K. (2004). India's emerging economy: Performance and prospects in the 1990s and beyond. Cambridge, Mass: MIT Press.

[5] Bolton, K. \& B.B. Kachru (2006). World Englishes: Critical concepts in linguistics. London: Routledge.

[6] Davies, P. (2008). New business in India: The 21st century opportunity. Singapore: Hackensack.

[7] Devonish, H., Seller, W. (1991). A reanalysis of the phonological system of Jamaican Creole. Society for Caribbean Linguistics Occasional Papers 24.

[8] Emmott, B. (2008). Rivals: How the power struggle between China, India and Japan will shape our next decade. London: Allen Lane.

[9] Fernandes, L. (2006). India's new middle class: Democratic politics in an era of economic reform. Minneapolis: University of Minnesota Press.

[10] Gargesh, R. (2008). Indian English: Phonology. In R. Mesthrie (eds.), Varieties of English: Africa, South and Southeast Asia. New York: Mouton de Gruyter, 231-243.

[11] Green, Lisa J. (2002). African American English: A linguistic introduction. Cambridge: Cambridge University Press.

[12] Hofland, K., Johansson, S. (1982). Word frequencies in British and American English. Bergen: Norwegian Computing Centre for the Humanities.

[13] Jenkins, J. (2000). The phonology of English as an international language: New models, new norms, new goal. Oxford: Oxford University Press.

[14] Jenkins, J. (2006). World Englishes: A resource book for students (Reprint ed.) London: Routledge.

[15] Kachru, B. B. (2004). Asian Englishes: Beyond the canon. Hong Kong: Hong Kong University Press.

[16] Kachru, Y., Smith, L. E. (2008). Cultures, contexts and world Englishes. London: Routledge.

[17] Kamdar, M. (2007a). Planet India: How the fastest-growing democracy is transforming America and the world. New York: Scribner.

[18] Kamdar, M. (2007b). Planet India: The rise and rise of the world's largest democracy. London: Simon and Schuster.

[19] Kamdar, M. (2007c). Planet India: The turbulent rise of the world's largest democracy. London: Pocket Books.

[20] Labov, W. (1985). The increasing divergence of black and white vernaculars introduction to the research reports (Typescript.)

[21] Lak, D. (2008). India express: The future of the new superpower (1st Palgrave Macmillan ed.) New York: Palgrave Macmillan.

[22] Ljung, M. (1990). A study of TEFL vocabulary. Stockholm, Sweden: Almqvist and Wiksell International.

[23] Masica, C. (1972). The sound system of general Indian English. Hyderabad, India: Central Institute of English.

[24] Meade, R. R. (2001). Acquisition of Jamaican phonology. Amsterdam: HIL.

[25] Meierkord, C. (2006). The sociolinguistics of lingua franca communication: Standardization and self-regulation. Berlin: Mouton de Gruyter.

[26] Meredith, R. (2007). The elephant and the dragon: the rise of India and China and what it means for all of us. W.W. New York: Norton.

[27] Mesthrie, R. (2008). Synopsis: The phonology of English in Africa and South and Southeast Asia. In R. Mesthrie (eds.), Varieties of English: Africa, South and Southeast Asia. New York: Mouton de Gruyter, 307-322.

[28] Nguyen, B. B-D. (1993). Accent discrimination and the test of spoken English: A call for an objective assessment of the comprehensibility of nonnative speaker. California Review 81, 1325- 1361.

[29] Nihalani, P. et al. (eds.) (2004). Indian and British English: A handbook of usage and pronunciation (2 ed.). New York: Oxford University Press.

[30] Peyawary, A. S. (1999). The core vocabulary of international English: A corpus approach. Bergen: Humanities Information Technologies Research Programme.

[31] Rajadhyaksha, N. (2007). The rise of India: Its transformation from poverty to prosperity. Chichester, England: John Wiley and Sons.

[32] Rickford, J. R. (1999). African American vernacular English: Features, evolutions, educational implications. Malden, Massachusetts: Blackwell Publishers Ltd. 
[33] Sailaja, P. (2009). Indian English. Edinburgh: Edinburgh University Press.

[34] Schneider, E. W. (2007). Postcolonial English: Varieties around the world. New York: Cambridge University Press.

[35] Sengupta, J. (2005). India's economic growth: A strategy for the new economy. New York: Palgrave Macmillan.

[36] Sheshabalaya, A. (2005). Rising elephant: The growing clash with India over white-collar jobs and its meaning for America and the world. Monroe: Common Courage Press.

[37] Smith, D. A. (2007). Growling tiger, roaring dragon: India, China and the new world order. Vancouver: Douglas and McIntyre.

[38] Tharoor, S. (2007). The elephant, the tiger, and the cell phone: Reflections on India, the emerging 21st-century power (1st ed.). New York: Arcade Pub. Distributed by Hachette Book Group USA.

[39] Trudgill, P. (2004). New-dialect formation: The inevitability of colonial Englishes. New York: Oxford University Press.

[40] Upton, C. (2008). Received pronunication. In B. Kortmann \& C. Upton (eds.), Varieties of English 1: The British isles. Berlin: Mouton de Gruyter, 237-252.

[41] Wassink, A. B. (1999). Historic Low Prestige and Seeds of Change: Attitudes toward Jamaican Creole. Language in Society 28 (1), 57-92.

[42] Wells, J. C. (1982). Accents of English. Cambridge: Cambridge University Press.

[43] Wolfram, W. \& N. Schilling-Estes (1998). American English: Dialects and variation. Malden, MA: Blackwell.

James H. Yang is Assistant Professor at National Yunlin University of Science and Technology, Taiwan. His research has recently focused on different English accents in attempt to construct the core English phonology for accommodating the needs of mutual intelligibility and national identities in the use of English as a lingua franca for international communication. 